\title{
TINJAUAN TEOLOGIS MENGENAI PROBLEMATIK KAUM MUDA MASA KINI
}

\author{
Kasieli Zebua \\ kasieli.zebua@sttia.ac.id
}

\section{Abstract:}

Youth as the next generation has a burden and responsibility put on his/ her shoulder that handed down by previous generations, because in themselves has great potential. However, this potential needs to be directed through good coaching from their parents or from the church. For the young people them selves also have huge problematic which is sin. Sin must be settled through redemption and forgiveness of Christ. If sin is not resolved, then all the potential in young people will tend to the negative things that ultimately lead to various problems in his/her life. In contrast, young people who have been set free from sin will be able to implement faith in the face of various challenges and temptations that come from outside. Young people will be able to maximize the potential in them to be a witness of Christ and to contribute as the next generation, whether in family, church, community, state and nation.

Keywords: Theological view, problematic, youth, contemporary.

\section{Abstrak:}

Kaum muda sebagai generasi penerus memiliki beban dan tanggung jawab di pundaknya yang diwariskan oleh generasi sebelumnya, sebab di dalam dirinya memiliki potensi yang besar. Namun, potensi ini perlu diarahkan melalui pembinaan, baik dari orang tua maupun dari gereja. Sebab dalam diri kaum muda juga memiliki problematik yang besar, yaitu dosa. Dosa harus diselesaikan melalui penebusan dan pengampunan Kristus. Apabila dosa tidak terselesaikan, maka segala potensi dalam diri kaum muda akan cenderung kepada hal yang negatif yang akhirnya menimbulkan berbagai problem dalam hidupnya. Sebaliknya, kaum muda yang telah dimerdekakan dari dosa akan mampu mengimplementasikan imannya dalam mengha dapi berbagai tantangan dan godaan yang datang dari luar. Kaum muda akan mampu memaksimalkan potensi dalam dirinya untuk menjadi saksi Kristus dan berkontribusi sebagai generasi penerus, baik dalam keluarga, gereja, masyarakat, bangsa dan negara. Kata-kata Kunci: Tinjauan teologis, problematik, kaum muda, masa kini.

\section{PENDAHULUAN}

Kapan masa paling sulit dalam kehidupan manusia? Apakah pada masa bayi? Masa remaja/pemuda? Masa dewasa? Atau masa usia lanjut? Mungkin setiap orang memiliki penilaian dan jawaban yang berbeda. Mungkin banyak yang mengatakan bahwa pada saat memasuki usia lanjut adalah masa yang paling sulit, tetapi masa mudalah - menurut penilaian penulis, periode yang paling menantang dan penuh tantangan, karena keberhasilan masa muda menentukan kebaikan hidup pada masa tua. Singgih D. Gunarsa menilai bahwa muda-mudi dengan masalah, pengalaman dan kesulitan-kesulitannya bila tidak memperoleh bimbingan dan pengarahan, akan seperti "layangan putus terbawa angin" yang entah di mana kelak tersangkut. ${ }^{1}$ Dan perhatian yang sama disampaikan oleh Mangunhardjana, ia berkata bahwa "masa muda bukanlah sekadar masa 
penantian; masa muda adalah masa untuk berharap, bermimpi, bercita-cita. Masa muda adalah masa untuk memberi arti kepada hidup dan masa untuk mengambil keputusan yang menentukan." 2 Artinya pada masa muda seseorang dituntut untuk berhasil atau gagal; menang atau kalah. Masa muda adalah masa menemukan arah hidup yang benar dan mengambil keputusan untuk menghidupinya.

Masalah yang dihadapi generasi muda sebenarnya tidak terpisah dari masalah secara umum yang berkembang di tengah-tengah masyarakat, karena pada hakekatnya generasi muda merupakan bagian yang tak terpisahkan dari masyarakat. Bentuk problem ditentukan oleh faktor dan keadaan yang ada pada generasi muda itu sendiri serta kondisi masyarakat yang bersangkutan. Kaum muda tidak dapat menghindar dari tantangan hidup, tetapi harus menghadapi dan menaklukkannya. Ketidakmampuan memahami tantangan ini menyebabkan begitu banyak anak muda yang kehilangan arah dan terjerat oleh keinginan dunia ini. Rasul Paulus mengingatkan Timotius yang masih muda mengenai kondisi ini, ia menuliskan:

Ketahuilah bahwa pada hari-hari terakhir akan datang masa yang sukar. Manusia akan mencintai dirinya sendiri dan menjadi hamba uang. Mereka akan membual dan menyombongkan diri, mereka akan menjadi pemfitnah, mereka akan berontak terhadap orang tua dan tidak tahu berterima kasih, tidak mempedulikan agama, tidak tahu mengasihi, tidak mau berdamai, suka menjelekkan orang, tidak dapat mengekang diri, garang, tidak suka yang baik, suka mengkhianat, tidak berpikir panjang, berlagak tahu, lebih menuruti hawa nafsu dari pada menuruti Allah. Secara lahiriah mereka menjalankan ibadah mereka, tetapi pada hakekatnya mereka memungkiri kekuatannya. Jauhilah mereka itu! (2 Tim. 3:1-5).

Sangat menarik bahwa Alkitab memberikan gambaran yang begitu jelas, transparan lengkap dengan segala kelebihan dan kelemahan dari seorang muda. Alkitab dengan jujur mencatat banyak anak-anak muda yang berhasil dalam mempertahankan imannya saat menghadapi tantangan hidup, tetapi juga mencatat kegagalan-kegagalan anak-anak muda menjalani imannya. Semua hal itu dicatat supaya kaum muda masa kini dapat belajar mengenal Allah melalui kehidupan kaum muda yang dicatat dalam Alkitab. Rasul Paulus mengingatkan bahwa “...segala sesuatu yang ditulis dahulu, telah ditulis untuk menjadi pelajaran bagi kita, supaya kita teguh berpegang pada pengharapan oleh ketekunan dan penghiburan dari Kitab Suci," (Rm. 15:4). Ada banyak ayat mengenai nasihat, teguran, prinsip, dan tuntunan kepada orang muda.

Dengan demikian di dalam tulisan ini, problematik yang dihadapi kaum muda masa kini akan ditinjau dari perspektif Alkitab. Alkitab tidak hanya menunjukkan masalah, kekeliruan dan dosa, tetapi juga memberi solusi yang tepat dan benar sehingga kaum muda yang percaya kepada Firman Tuhan akan menang atas tantangan dan problem yang dihadapi, bahkan menjadi saksi Kristus melalui keubahan hidup yang dialami. 2 Timotius 3:16-17 menyatakan bahwa "Segala tulisan yang diilhamkan Allah memang bermanfaat untuk mengajar, untuk menyatakan kesalahan,

\footnotetext{
${ }^{2}$ A. M. Mangunhardjana, Pendampingan Kaum Muda (Yogyakarta: Kanisius, 1986), 19.
} 
untuk memperbaiki kelakuan dan untuk mendidik orang dalam kebenaran. Dengan demikian tiaptiap manusia kepunyaan Allah diperlengkapi untuk setiap perbuatan baik."

Maka melalui tulisan ini, penulis menjelaskan beberapa poin penting terkait perspektif Alkitab terhadap problematik kaum muda masa kini, yaitu potensi dan problematik kaum muda, urgensi pembinaan terhadap kaum muda serta peranan orang tua dan gereja dalam pembinaan kaum muda.

\section{POTENSI DAN PROBLEMATIK KAUM MUDA}

Siapakah Kaum Muda? Kaum muda adalah mereka yang berada pada masa proses peralihan dari masa kanak-kanak menuju masa dewasa, yaitu usia 16-30 tahun. ${ }^{3}$ Masa ini merupakan masa yang paling menentukan perkembangan emosional, moral, spiritual dan fisik seseorang. Pada masa ini, seseorang mengalami perubahan besar yang berlangsung dalam tempo yang singkat. Dan dalam waktu yang singkat itu, terbentuk kepribadian manusia, dan serentak juga proses pengarahan menuju kematangannya. ${ }^{4}$ Kaum muda adalah mereka yang berada dalam periode pemantapan identitas diri. Dalam proses ini, situasi-situasi yang terjadi dalam lingkugan masyarakatnya sangat berpengaruh dalam menemukan dan mengartikan keadaan hidup mereka.

\section{Potensi dalam Diri Kaum Muda}

Allah menciptakan setiap manusia tidak "apa adanya" atau sekadar saja. Tuhan menciptakannya dengan potensi ${ }^{5}$ yang besar untuk tujuan yang mulia. Kejadian 1:26-27, "Berfirmanlah Allah: "Baiklah Kita menjadikan manusia menurut gambar dan rupa Kita, supaya mereka berkuasa atas ikan-ikan di laut dan burung-burung di udara dan atas ternak dan atas seluruh bumi dan atas segala binatang melata yang merayap di bumi. Maka Allah menciptakan manusia itu menurut gambar-Nya, menurut gambar Allah diciptakan-Nya dia; laki-laki dan perempuan diciptakan-Nya mereka.” Manusia diciptakan segambar dan serupa dengan Allah memiliki potensi dan kemampuan khusus yang tidak dimiliki oleh ciptaan lainnya. ${ }^{6}$

Salomo melihat bahwa anak muda identik dengan kekuatannya. Mereka memiliki daya, kemampuan, semangat. Salomo berkata bahwa "Hiasan orang muda ialah kekuatannya, dan

\footnotetext{
33 Penetapan usia bagi pemuda ini sedikit beragam. Menurut Undang-Undang RI Nomor 40 tahun 2009 pasal 1 ayat 1 , pemuda adalah warga negara Indonesia yang memasuki periode penting pertumbuhan dan perkembangan yang berusia 16-30 tahun; menurut UNESCO yang dapat disebut sebagai pemuda adalah mereka yang berusia antara 15-24 tahun; The African Youth Charter, pemuda adalah mereka yang berusia antara 15-35 tahun; sedangkan WHO menetapkan kelompok umur 18-65 tahun sebagai pemuda.

${ }^{4}$ John Dami Mukese, Menjadi Manusia Kaya Makna (Jakarta: Obor, 2006), 47.

${ }^{5}$ Menurut KBBI, potensi adalah kemampuan yang mempunyai kemungkinan untuk dikembangkan; kekuatan; kesanggupan; daya.

${ }^{6}$ Gambar (tselem) dan rupa Allah (demût) menyatakan bahwa manusia pada hakikatnya diciptakan berbeda dengan semua jenis hewan. Manusia memiliki kedudukan yang jauh lebih tinggi, yang mampu berhubungan dan bersekutu dengan Khaliknya. Manusia dapat menanggapi dan bertanggung jawab kepada Allah serta diberikan hak untuk memilih. Manusia sebagai wakil dan penatalayanan Allah yang bertanggung jawab di bumi, melaksanakan kehendak dan menanggapi maksud Sang Khalik. Manusia diberi kuasa untuk menguasai dan memelihara bumi. Charles F. Pfeiffer dan Everett F. Harrison (ed.), The Wyclif Bible Commentary ed. Bahasa Indonesia (Malang: Gandum Mas, 2004), 29-30.
} 
keindahan orang tua ialah uban." (Ams. 20:29). Inilah satu periode dalam hidup manusia ketika aspek kekuatan fisik menjadi kebanggaan. Salomo dengan jelas menyatakan bahwa kekuatan inilah yang menjadi keunikan dari orang muda. Anak muda memiliki kemampuan untuk bergerak dan bertindak. Tidak heran, jika hal ini akhirnya menjadi modal utama bagi anak muda untuk melakukan eksplorasi, mencoba hal-hal baru. 1 Yohanes 2:14c, "Aku menulis kepada kamu, hai orang-orang muda, karena kamu kuat dan firman Allah diam di dalam kamu dan kamu telah mengalahkan yang jahat.” Apa yang ditulis oleh rasul Yohanes bahwa pemuda adalah orang-orang kuat dalam firman Allah dan mampu mengimplementasikan imannya sehingga mengalahkan kuasa si jahat atau setan. Dalam sejarah Alkitab, beberapa contoh seperti Yusuf (Kej. 37-41), Daniel, Sadrakh, Mesakh dan Abednego dalam kitab Daniel telah memberikan bukti yang nyata.

Philips Tangdilintin menilai pada periode ini, anak muda memiliki perkembangan yang pesat akan pemikiran abstrak, penemuan identitas diri secara psikologis, dan keinginan untuk dapat hidup mandiri. Inilah suatu masa di mana seseorang dipenuhi dengan kekuatan dan vitalitas, sekaligus kekuatan menghadapi badai, konflik, dan stress. ${ }^{7}$

\section{Potensi Untuk Berkontribusi}

Peran anak muda di dalam Alkitab ternyata cukup banyak dan berperan besar. Kisah-kisah di dalam Alkitab ingin menunjukkan bahwa anak muda bukanlah kaum yang direndahkan. Anakanak muda juga memiliki andil penting dalam menyatakan karya Allah. Anak muda juga memiliki kualitas yang patut dibanggakan.

\section{Kontribusi Bagi Keluarga}

Mazmur 127:4-5, "Seperti anak-anak panah di tangan pahlawan, demikianlah anak-anak pada masa muda. Berbahagialah orang yang telah membuat penuh tabung panahnya dengan semuanya itu. Ia tidak akan mendapat malu, apabila ia berbicara dengan musuh-musuh di pintu gerbang." Mazmur 127 merupakan mazmur keluarga, ${ }^{8}$ dan pemazmur mengungkapkan bahwa anak-anak muda memiliki peran yang signifikan bagi orang tua dan keluarga, mereka merupakan alat yang bisa digunakan untuk kebaikan dan yang dapat melindungi mereka dari musuh. Anak sebagai karunia Allah (ay. 3) yang menjadi kebanggaan bagi orang tua dan yang dapat diandalkan.

\section{Kontribusi Bagi Umat dan Masyarakat}

Yeremia 1:6-8, "Maka aku menjawab: “Ah, Tuhan Allah! Sesungguhnya aku tidak pandai berbicara, sebab aku ini masih muda." Tetapi TUHAN berfirman kepadaku: "Janganlah katakan: Aku ini masih muda, tetapi kepada siapa pun engkau Kuutus, haruslah engkau pergi, dan apapun

${ }^{7}$ Philips Tangdilintin, Pembinaan Generasi Muda (Yogyakarta: Kanisius, 2008), 27.

${ }^{8}$ Robert Jamieson, dkk., A Commentary Critical, Experimental, and Practical On The Old and New Testament - Volume two part one (Grand Rapids, Michigan: William B. Eerdmans Publishing Company, 1984), 381. 
yang Kuperintahkan kepadamu, haruslah kausampaikan. Janganlah takut kepada mereka, sebab Aku menyertai engkau untuk melepaskan engkau, demikianlah firman TUHAN."' Allah memakai Yeremia yang masih muda untuk menyampaikan firman Tuhan kepada bangsa Israel yang tegar tengkuk. Juga pemuda yang jauh sebelum Yeremia ada, yaitu Yusuf. Allah memakai Yusuf untuk menyatakan rencana-Nya bagi Israel (Kej. 37-41). Demikian juga Tuhan memakai Daniel, Sadrakh, Mesakh dan Abednego untuk menyatakan kebesaran-Nya di negeri Babel. Mereka mampu menyatakan iman mereka (lihat Kitab Daniel).

\section{Kontribusi Bagi Jemaat}

1 Timotius 4:12, "Jangan seorang pun menganggap engkau rendah karena engkau muda. Jadilah teladan bagi orang-orang percaya, dalam perkataanmu, dalam tingkah lakumu, dalam kasihmu, dalam kesetiaanmu dan dalam kesucianmu." Secara khusus Rasul Paulus menasihati Timotius bagaimana harus hidup dan berperan bagi jemaat sebagai orang muda. Bagi Paulus peran anak muda dalam jemaat sangat penting bagi pertumbuhan gereja (bnd. 1Tim. 1:3-4; 1 Kor. 4:17; 6:10).

\section{Problematik dalam Kehidupan Kaum Muda}

Setiap manusia mengalami dua aspek problematik terbesar yang memengaruhi seluruh tatanan dan nilai hidupnya, yaitu problematik internal dan eksternal. Kedua problematik ini saling memengaruhi, tetapi yang memegang kendali ialah problematik internal.

\section{Problematik Internal}

Problematik internal merupakan problem yang ada di dalam diri kaum muda sebagai keturunan Adam, yaitu dosa9 (Rm. 5:12-19, bnd. 1 Ptr. 1:18). Tidak seorang pun dilahirkan dalam kondisi polos secara moral, tanpa dosa kecuali Yesus Kristus. Alkitab mengajarkan bahwa setiap manusia lahir dengan natur berdosa. Natur manusia yang berdosa ini menjelaskan mengapa tak

\footnotetext{
${ }^{9}$ Dalam PL ada beberapa kata untuk dosa yang pokok artinya adalah "tidak kena". Dalam PB dosa adalah "a nomia" (1Yoh. 3:4). Jadi, dosa adalah perbuatan yang tidak sesuai dengan kehendak Allah. Dosa mungkin perbuatan terhadap orang lain karena perbuatan demikian itu juga dinormir, dinilai, oleh kehendak Allah. Demikianlah dosa selalu dilihat dalam hubungan manusia dengan Allah. Dosa bukan sesuatu, bukan substansi, yang memasuki hidup manusia, melainkan arah dalam hati dan pikiran yang membelokkan arah itu 180o, bukan untuk melayani Tuhan tapi mau melayani diri (Kej. 3:5). Oleh karena itu dosa bukan hanya kekurangan melainkan kekurangan yang memengaruhi sehingga arah menjadi salah. Alkitab menceritakan bahwa manusia pertama yang diciptakan "sungguh amat baik" itu terselewengkan oleh ketinggian hatinya dan memberontak terhadap Tuhan. Karena ia adalah wakil dari segala keturunannya maka kesalahan pemberontakan ini juga diperhitungkan kepada segala keturunannya itu. Inilah yang disebut dosa warisan. Karena manusia meninggalkan Tuhan, satu-satunya sumber hidup, maka ia hanya menuju ke maut dan hidupnya menjadi rusak, R. Soedarmo, Kamus Istilah Teologi (Jakarta: BPK Gunung Mulia, 2011), 21-22. Semua orang dirasuki oleh dosa dan kesalahannya menyombongkan diri dan bukan iman (Rm. 5:12 dst.). Keadaan ini tidak dapat diubah oleh upaya manusia (Rm. 7) dan hanya oleh prakarsa Allah sendiri suatu perubahan dapat terjadi (Yoh. 3:3 dst.). Secara mendasar dosa itu ditaklukkan oleh hidup, kematian, dan kebangkitan Yesus Kristus, dan kita dilepaskan dari kuasa yang mencekik oleh persekutuan kita dengan Kristus dalam iman dan baptisan, W.R.F. Browning, Kamus Alkitab (Jakarta: BPK Gunung Mulia, 2011), 85.
} 
seorang pun perlu diajari untuk berbuat dosa. Dosa secara alami menghampiri setiap orang karena dosa memang bagian dari natur manusia.

Beberapa bagian Alkitab baik Perjanjian Lama maupun Perjanjian Baru dengan jelas mencatat bahwa setiap manusia adalah orang berdosa. 1 Raja-raja 8:46, “... Tidak ada manusia yang tidak berdosa...." (bnd. Mzm. 143:2; Ams. 20:9; Pkh. 7:20; Mzm. 51:7). Rasul Paulus menulis dalam Roma 3:10,12, "Tidak ada yang benar, seorang pun tidak ... tidak ada yang berbuat baik, seorang pun tidak." Kemudian ia melanjutkan "Karena semua orang telah berbuat dosa dan telah kehilangan kemuliaan Allah..."(Rm. 3:23). Rasul Yohanes juga melihat hal yang sama dalam 1 Yohanes 1:8, "Jika kita berkata, bahwa kita tidak berdosa, maka kita menipu diri kita sendiri dan kebenaran tidak ada di dalam kita."

Tuhan Yesus sendiri mengajarkan bahwa perbuatan dosa dan kefasikan merupakan perwujudan hati manusia yang penuh dosa. Yesus berkata: "Dari buahnyalah kamu akan mengenal mereka. Dapatkah orang memetik buah anggur dari semak duri atau buah ara dari rumput duri? Demikianlah setiap pohon yang baik menghasilkan buah yang baik, sedang pohon yang tidak baik menghasilkan buah yang tidak baik. Tidak mungkin pohon yang baik itu menghasilkan buah yang tidak baik, ataupun pohon yang tidak baik itu menghasilkan buah yang baik." (Mat. 7:16-18). Dan lagi Yesus berkata: "Tidak tahukah kamu bahwa segala sesuatu yang masuk ke dalam mulut turun ke dalam perut lalu dibuang di jamban? Tetapi apa yang keluar dari mulut berasal dari hati dan itulah yang menajiskan orang. Karena dari hati timbul segala pikiran jahat, pembunuhan, perzinahan, percabulan, pencurian, sumpah palsu dan hujat. Itulah yang menajiskan orang. Tetapi makan dengan tangan yang tidak dibasuh tidak menajiskan orang.” (Mat. 15:17-20).

Dengan demikian problematik utama kaum muda ialah dosa. Dosa yang melekat dalam diri, merasuk jiwa dan hati dan kemudian menghasilkan perbuatan-perbuatan dosa yang melawan Allah.

\section{Problematik Eksternal}

Dosa dan akibat dosa telah menimbulkan berbagai masalah dalam kehidupan manusia. Dosa telah merusak potensi yang Tuhan ciptakan dalam diri manusia. Segenap potensi dalam diri manusia, baik kecerdasan intelektual (IQ), kecerdasan spiritual (SQ) dan kecerdasan emosional $(\mathrm{EQ})^{10}$ cenderung digunakan untuk kepentingan diri sendiri yang bertentangan dengan kehendak Penciptanya (bnd. Kej. 6:5). Segala hal yang baik yang Tuhan sediakan menjadi rusak sehingga

${ }^{10} 10$ Intellegent Quotient (IQ) / Kecerdasan Intelektual meliputi: 1) Kecerdasan visual/spasial (kecerdasan gambar), 2) Kecerdasan verbal/linguistik (kecerdasan berbicara), 3) Kecerdasan musik, Kecerdasan logis/matematis (kecerdasan angka), 4) Kecerdasan interpersonal (cerdas diri), 5) Kecerdasan intrapersonal (cerdas bergaul). Emotion Quotient (EQ) atau Kecerdasan Emosi meliputi: 1) Kecakapan pribadi, Kesadaran diri, 2) Pengaturan diri, 3) Motivasi, 4) Kecakapan sosial, 5) Empati, 6) Ketrampilan sosial. Sedangkan Spiritual Quotient (SQ) atau Kecerdasan Spiritual dengan ciri-ciri: 1) Memiliki prinsip dan visi yang kuat, 2) Mampu melihat kesatuan dalam keanekaragaman, 3) Mampu memaknai setiap sisi kehidupan, 4) Mampu mengelola dan bertahan dalam kesulitan dan penderitaan. (http://www.iptek.info/2014/10/pengertian-potensi-diri-iq-eq aq-dan-sq.html - diakses 22 Juni 2016). 
menimbulkan berbagai masalah dalam kehidupan kaum muda karena ketidakmampuan merespons sesuai kehendak Tuhan. ${ }^{11}$

Apabila problematik internal, yaitu dosa tidak diselesaikan, maka hal apapun yang datang dari luar, baik hal yang positif apalagi hal yang negatif akan sangat berkuasa menggoda dan memengaruhi kaum muda untuk melakukan sesuatu yang bertentangan dengan kehendak Allah. Apabila problematik internal masih melekat dalam kehidupan kaum muda, maka segala potensi yang dimiliki akan merespons segala hal untuk kepentingan diri sendiri dan bukan untuk Tuhan.

Berbagai hal positif seperti perkembangan ilmu pengetahuan, teknologi dan informasi canggih melalui internet dan media sosial, yang seharusnya membuat anak-anak muda semakin bertumbuh dan berkembang dalam wasasan dan semakin efektif dalam melayani, tetapi ironisnya hal itu justru menjadi jerat yang membawa begitu banyak anak muda jatuh dalam dosa. Alasannya hanya satu, yaitu hati mereka belum dibaharui sehingga hati yang kotor dan licik ini tidak mampu memfilter, memilah dan merespons dengan baik, akibatnya mereka jatuh dalam dosa (Yer. 17:9; Ams. 22:15a). Hasilnya timbul berbagai masalah, baik dosa pornografi, dosa seks yang tidak menghargai nikah kudus, kepentingan diri sendiri dan tidak menghargai dan merugikan orang lain, dan berbagai masalah lainnya. Masalah ini akhirnya menjadi masalah sosial yang menjadi tantangan kaum muda bahkan dari generasi ke generasi selanjutnya dimana Iblis menungganginya da menjadikannya sebagai kendaraan untuk merusak anak-anak muda (bnd. 1Yoh. 5:9b).

Dengan demikian, apa yang harus dilakukan? Apakah dengan menjauhkan anak-anak muda dari perkembangan ilmu pengatahuan dan teknologi? Menjauhkan mereka dari penggunaan internet dan media sosial? Menjauhkan mereka dari pergaulan sosial? Tentu saja jawabannya: Tidak! Sebab dosa sudah berkembang sebelum semua ini ada. Apa yang dibutuhkan oleh anak muda adalah Kristus yang menyelesaikan masalah internalnya, yaitu dosa.

\section{URGENSI PEMBINAAN TERHADAP KAUM MUDA}

\section{Kaum Muda sebagai Generasi Penerus (Next Generation)}

Ungkapan yang familiar yang sering dikumandangkan ketika berbicara mengenai kaum muda: "Pemuda adalah Harapan Gereja" atau "Pemuda adalah Generasi Penerus Gereja" atau

\footnotetext{
${ }^{11}$ Dalam beberapa artikel, dijelaskan bahwa masalah yang dihadapi anak muda saat ini antara lain: 1) Anak mudah bermasalah dengan orang tuanya, 2) Anak muda hidup dalam konflik batin dan citra diri yang buruk, 3) Anak muda tidak mengetahui dengan jelas destinasi hidupnya, 4) Anak muda ingin mewujudkan angan-angan dan impiannya tetapi terhambat oleh berbagai faktor, 5) Anak muda memiliki masalah dalam hal teman hidup, dan 6) Anak muda terjerumus kepada pergaulan yang buruk dan rusak. (Sherlynda Oktavia, 6 Permasalahan Anak Muda Yang Harus Kita Ketahui! Baca: http://indonesiaone.org/6-permasalahan-umum-anak-muda-yang-harus-kita-ketahui/ (diakses 18 Juni 2016); Sedangkan Drew Kuehl menyampaikan 10 tantangan terbesar yang dihadapi kaum muda saat ini yakni: 1) Personalizing/living out your faith, 2) Living in an anti-Christian culture, 3) Sexual purity pressures/temptations, 4) Identity and self-image issues, 5) Divorce and family issues, 6) Negative media influences, 7) Busyness, 8) Absent father figures, 9) Lack of discipline, 10) Materialism (Baca: http://www.searchthescriptures.org/blog/ what-are-the-ten-biggestchallenges-christian-youth-are-facing-today (diakses 18 Juni 2016).
} 
"Pemuda adalah Penerus Pekerjaan Tuhan" atau ungkapan senada lainnya. Ungkapan ini begitu bersemangat dan penuh harapan. Ungkapan ini menyatakan visi yang besar ke masa depan. Seperti disampaikan oleh Budi Abdiputra bahwa gereja yang visioner adalah gereja yang memperhati kan generasi berikutnya. ${ }^{12}$ Gereja melihat betapa pentingnya kaum muda sebagai generasi penerus bagi visi misi yang Tuhan tetapkan bagi gereja-Nya.

Amanat Agung Tuhan Yesus dalam Matius 28:18-19, Yesus mendekati mereka dan berkata: "Kepada-Ku telah diberikan segala kuasa di sorga dan di bumi. Karena itu pergilah, jadikanlah semua bangsa murid-Ku dan baptislah mereka dalam nama Bapa dan Anak dan Roh Kudus, dan ajarlah mereka melakukan segala sesuatu yang telah Kuperintahkan kepadamu. Dan ketahuilah, Aku menyertai kamu senantiasa sampai kepada akhir zaman." (bnd. Mrk. 16:15; Luk. 24:47-48; Kis. 1:8). Gereja adalah sebuah wadah yang mendidik dan menuntun pemuda kepada tatanan hidup dan kehidupan yang benar, sedangkan pemuda gereja merupakan generasi penerus yang akan menentukan masa depan gereja dengan meneruskan perjuangan gereja di masa-masa yang akan datang. Dalam pelayanan gereja untuk mewujudkan Amanat Agung Tuhan Yesus Kristus, pemuda gereja adalah subyek sekaligus obyek pelayanan.

\section{Tantangan Kehilangan Generasi Muda (Lost Generations)}

Eropa sebelum abad ke-19 boleh dikatakan merupakan pusat kekristenan dunia. Dari sinilah kekristenan tersebar ke seluruh dunia. Akan tetapi, beberapa survei menunjukkan bahwa pada saat ini kekristenan di Eropa mengalami penurunan drastis. Banyak orang sudah enggan ke gereja lagi. Baik di Amerika dan di beberapa negara di Eropa telah terjadi degradasi iman kekristenan. Banyak gedung gereja yang kosong tidak ada aktivitas peribadahan, bahkan dijual dan kemudian berubah fungsi. Ada yang menjadi ruang pameran, tempat hiburan, atau museum. Tidak sedikit juga orang-orangnya yang berpindah pada agama yang lain. Mengapa hal ini terjadi? Beberapa pengamat menyimpulkan bahwa keadaan ini terjadi oleh karena kehilangan generasi (the lost generation).

Harianto GP mengutip hasil riset yang dikerjakan oleh Ron Hutchcraft, "Youth for Christ Director for Metro New York" mengatakan pembangunan yang terjadi terhadap pemuda di Amerika adalah "Lost Generations" sebagai berikut:

Tahun 1950, pemuda sudah tidak merasa berdosa apa yang mereka lakukan baik dengan musik, bioskop, mobil atau dengan uangnya. Mereka menemukan kebebasan hidup. Justru mereka bersalah kalau tidak hidup bebas. Tahun 60- an, otoritas agama (Alkitab) sudah hilang. Bukan cuma otoritas agama, tetapi otoritas orang tua bahkan pemerintah. Tahun 70-an, mereka kehilangan kasih. Mereka berasal dari families broke and kids hungry. Ia justru belajar mengasihi dirinya sendiri, bukan orang lain. Tahun 80-an, anak-anak muda telah kehilangan harapan. Mereka merasa segala sesuatunya karena dirinya sendiri. Mereka cenderung mengarah ke tidakberagama. ${ }^{13}$

\footnotetext{
${ }^{12}$ Budi Abdiputra, Generasi Pembaru (Yogyakarta: Andi Offset, 2009), 17.

${ }^{13}$ Harianto GP, Mission for City (Bandung: Agimedia, 2006) 184.
} 
Kondisi yang sama pernah terjadi dalam kehidupan bangsa Israel (Yos. 24:31; Hak. 2:7). Pada masa kepemimpinan Yosua, mereka menyembah kepada Allah. Akan tetapi, kondisinya jauh berbeda setelah Yosua meninggal. Generasi berikutnya tidak lagi mengenal Tuhan dan karya yang telah dilakukan-Nya bagi bangsa Israel. Bahkan mereka menyembah kepada ilah-ilah lain (Hak. 2:12-13). Tuhan ingin umat Tuhan membawa bangsa lain datang kepada-Nya, tetapi faktanya generasi penerus ini tidak memahami maksud Tuhan, dan malahan mengikuti penyembahan berhala bangsa lain. Maka tidak heran jika hal ini membangkitkan murka Tuhan atas mereka (Hak. 2:14-15). Tangdilintin menuliskan dalam bukunya "Pembinaan Generasi Muda" bahwa tak dapat dipungkiri kenyataan bahwa salah satu penyebab lambannya gerak pembaruan dalam gereja adalah karena potensi perubahan dan pembaruan, yakni generasi mudanya, diabaikan. Mereka lebih banyak 'diparkir di pinggiran' atau malah 'di belakang', menunggu giliran berperan 'nanti kalau sudah dewasa. Dengan itu potensi sebagai agent of change dimarginalkan dan dimubazirkan. ${ }^{14}$

Berdasarkan fakta di atas, maka pembinaan kepada kaum muda adalah suatu keharusan yang mendesak. Baik orang tua maupun para pemimpin gereja harus memberi perhatian yang serius kepada kaum muda, sehingga mereka tidak terjerat dalam kondisi kehidupan di akhir zaman ini (bnd. 2 Tim. 3:1-5).

\section{PERANAN ORANG TUA \& GEREJA DALAM PEMBINAAN KAUM MUDA}

Pembinaan kepada anak muda terutama dimulai dari keluarga. Orang tua memiliki peranan yang sangat penting dan utama. Selain orang tua dan keluarga, gereja juga memiliki peranan yang besar. Sekolah dan lingkungan juga turut mengambil andil yang tak kalah penting dalam pembinaan anak muda, namun dalam tulisan ini hanya dibahas peranan orang tua dan gereja.

\section{Peranan Orang Tua dalam Pembinaan Anak Muda}

Amsal 22:6, "Didiklah orang muda menurut jalan yang patut baginya, maka pada masa tuanya pun ia tidak akan menyimpang dari pada jalan itu." Firman Tuhan ini ditujukan terutama kepada orang tua untuk mendidik anaknya di jalan yang benar dan berkenan kepada Tuhan. Orang tua harus terlebih dahulu mengerti dan mengenal jalan yang benar itu. Orang tua bertanggung jawab untuk mengarahkan anak muda agar hidup menurut jalan yang ditunjukkan Tuhan, dengan melakukan kebenaran dan keadilan. Kegagalan orang tua mengenal kebenaran ini akan menyebabkan pendidikan yang salah dan menyimpang. Orang tua yang mengasihi anaknya dan mengharapkan masa depan bahagia harus terlebih dahulu mengasihi Tuhan dan hidup menurut

${ }^{14}$ Philips Tangdilintin, Pembinaan Generasi Muda, 38-39. 
jalan Tuhan. Orang tua dituntut menjadi teladan bagi anaknya. ${ }^{15}$ Orang tua tidak hanya mencukupkan kebutuhan jasmani tetapi juga harus menjadi pemimpin rohani bagi anak-anaknya. Sehingga Augusto Cury dalam bukunya Briliant Parents Fascinating Teachers mengemukakan dua tipe orang tua, yakni orang tua yang baik dan orang tua yang hebat. Cury menjelaskan bahwa orang tua yang baik, dengan cara mereka, selalu berusaha memenuhi harapan anak. Mereka merayakan ulang tahun anak; membeli sepatu, pakaian, barang elektronik dan mengajak bertamasya. Tetapi orang tua yang hebat memberikan sesuatu yang tak ternilai. Sesuatu yang tidak dapat dibeli dengan seluruh uang yang ada di dunia ini, yakni diri mereka sendiri, cerita, pengalaman, air mata, dan waktu mereka. ${ }^{16}$ Orang tua yang hebat akan mempedulikan kesejahteraan rohani anak dan berusaha menuntun mereka kepada hubungan yang setia dengan Allah. Untuk mencapai kesejahteraan rohani ini dibutuhkan perhatian intensif dan di siplin yang tinggi seperti diungkapkan dalam Ulangan 6:6-7, “Apa yang kuperintahkan kepadamu pada hari ini haruslah engkau perhatikan, haruslah engkau mengajarkannya berulang-ulang kepada anakanakmu dan membicarakannya apabila engkau duduk di rumahmu, apabila engkau sedang dalam perjalanan, apabila engkau berbaring dan apabila engkau bangun." Kata Ibrani untuk "mendidik" berarti "to train" dan "dedicate", ${ }^{17}$ yaitu "melatih" atau "mengabdikan". Jadi, didikan orang tua bertujuan melatih dan mengabdikan anak kepada Allah dan kehendak-Nya.

Orang tua yang bijaksana akan mendidik "menurut jalan yang patut" bagi anaknya. Orang tua harus memahami bahwa begitu banyak jalan yang tidak patut, jalan yang tidak sesuai, jalan yang sesat di hadapan anak muda. Bahkan orang tua dituntut untuk memahami jalan pikiran dan dunia anak muda. Dengan kemajuan teknologi dan ilmu pengetahuan, maka segala hal terbuka bagi mereka. Pada zaman ini, tidak ada sesuatu yang bersifat rahasia bagi anak muda. Segala kemungkinan terpampang di depan mata. Selain memahami kebenaran Firman Allah, orang tua juga wajib memahami kesesatan dunia ini, sehingga mampu menolong anak muda menemukan jalan yang benar.

Kegagalan orang tua memahami dunia anak muda zaman ini akan menyebabkan gap yang begitu lebar yang akhirnya sulit untuk diseberangi. James W. Boyd mengatakan bahwa justru masalah utama yang dihadapi anak muda saat ini adalah kesenjangan komunikasi antara mereka dan orang tua. ${ }^{18}$ Sesungguhnya anak muda menghadapi begitu banyak problem. Ketika orang tua tidak mau atau enggan memahami problem ini, maka nasihat yang brilian sekalipun akan dianggap sebagai ancaman bagi kesenangan anak muda. Oleh sebab itu kehadiran orang tua sangat penting

\footnotetext{
${ }^{15}$ Salah satu masalah yang dihadapi anak muda saat ini ialah krisis keteladanan. Kaum muda tidak menemukan teladan iman, karakter bahkan moral yang baik dalam diri orang tua bahkan pimpinan-pimpinan gereja di dalam menghadapi tantangan hidup di dunia ini.

${ }^{16}$ Augusto Cury, Briliant Parents Fascinating Teachers - Kiat membentuk Generasi Muda yang Cerdas dan Bahagia (Jakarta: Gramedia Pustaka Utama, 2007), 3.

${ }^{17}$ BibleWorks 8, (Strong 2596).

${ }^{18} 18$ James W. Boyd, “O, Give Me A Home” Number 37: Today's Youth Facing Today's Problems. Dapat dilihat di http://www.dawn.com/news/965881/problems-faced-by-the-youth-today (Diakses 20 Juni 2016).
} 
dalam membantu anak muda mengimplementasikan imannya dalam menghadapi problem kehidupan sehari-hari. Orang tua harus membangun komunikasi yang harmonis dengan baik. Bukan hanya mampu menyampaikan teguran dan larangan, tetapi menciptakan pemahaman yang baik dan benar seperti yang disampaikan oleh Donald K. Smith bahwa komunikasi adalah menciptakan pemahaman sampai pemahaman telah berkembang. ${ }^{19}$ Artinya bahwa orang tua membantu memberi pemahaman bagi anak muda sehingga mampu mengambil keputusan yang tepat dalam hidupnya.

\section{Peranan Gereja dalam Kehidupan Anak Muda}

Kaum muda gereja selalu mencari kepuasan sama halnya dengan pemuda yang lain di segala tempat. Mereka mengharapkan gereja memenuhi kebutuhannya. Menurut pengamatan Selvester M. Tacoy, ada empat hal yang dicari kaum muda masa kini ketika datang ke gereja: ${ }^{20}$ Pertama, kaum muda mencari teman, sahabat atau pacar. Mereka mencari sahabat yang dapat diajak untuk berbagi suka dan duka, yang siap dijadikan tempat untuk mencurahkan isi hatinya atas berbagai masalah dan pergumulan yang dihadapinya. Kedua, kaum muda mencari figur pemimpin yang dapat diteladani. Dalam hal itu, figur yang dicari oleh kaum muda di gereja adalah para pemimpin rohani yang dapat mengayomi dan mendengarkan apa yang dihadapi oleh mereka sehari-hari serta dapat memberikan bimbingan. Ketiga, kaum muda mencari khotbah yang menjawab kebutuhannya. Khotbah yang tidak menjawab kebutuhan menyebabkan kaum muda enggan untuk datang ke gereja. Bahkan mereka yang sudah ada di gereja dapat pergi meninggalkan gereja, lalu mencari gereja lain yang dapat memenuhi kebutuhan mereka. Keempat, kaum muda mencari ibadah (musik/pujian) yang sesuai dengan konteks mereka. Bagi mereka musik sebagai identitas diri.

Tacoy melanjutkan bahwa bila keempat hal ini mereka tidak temukan dalam gereja, maka akan timbul konflik dalam hatinya. Mereka menghendaki terjadinya perubahan dalam gereja sesuai dengan konteks mereka, bahkan tidak jarang mereka keliling untuk mencari ibadah yang sesuai dengan kebutuhannya untuk suatu kepuasan. Sehubungan dengan hal itu, Tim Wright mengungkapkan bahwa: "Sekarang ini orang (kaum muda) memilih gereja sama seperti memilih segala sesuatu yang lain sebagai konsumen. Mereka bergerak ke mana ada aksi, di mana mereka berpikir kebutuhannya akan terpenuhi tanpa mempedulikan apapun, doktrin, atau pun lokasi." ${ }^{21}$

Mengamati fenomena di atas maka gereja harus bijaksana dan mampu mengakomodir kebutuhan kaum muda gereja masa kini. Gereja harus hadir untuk mengarahkan kaum muda dalam memenuhi kebutuhan mereka. Gereja tidak boleh mengganggap bahwa motivasi kaum muda datang ke gereja sema ta-mata memuaskan keinginan diri sendiri. Gereja tidak boleh menutup

\footnotetext{
${ }^{19}$ Donald K. Smith, Creating Understanding. Ed. Bahasa Indonesia (Yogyakarta: ANDI, 2014) 485.

${ }^{20} 20$ Selvester M. Tacoy, 6 Kunci Sukses Pelayanan Kaum Muda (Bandung: Kalam Hidup, 2009), 46-49.

${ }^{21}$ Selvester M. Tacoy, 6 Kunci Sukses Pelayanan Kaum Muda, 45.
} 
mata sehingga tidak memberi perhatian kepada kebutuhan tersebut. Tetapi gereja harus mampu mengubah paradigma dengan menjadikan kebutuhan tersebut menjadi sarana untuk mempertemukan kaum muda kepada Kristus sampai mereka menjadi murid Kristus yang sejati.

\section{Mempertemukan Kaum Muda dengan Kristus}

Gereja yang sehat memiliki tujuan pelayanan yang jelas dan terarah. Tujuan pelayanan kepada kaum muda yang paling mendasar ialah mempertemukan kaum muda dengan Kristus. Segala bentuk program dalam pembinaan kaum muda akan bermakna apabila tujuan ini tercapai. Paradigma pelayanan ini akan menghasilkan kaum muda yang mengenal, percaya dan menerima Kristus sebagai satu-satunya Juruselamat pribadinya. Segala motivasi dan kerinduan kaum muda ketika datang ke gereja harus diarahkan kepada motivasi ini.

Perjumpaan pribadi dengan Kristus merupakan jantung pelayanan bagi kaum muda. Perjumpaan pribadi bukan hanya suatu kerinduan tetapi suatu kebutuhan hakiki. Kaum muda bisa mendapatkan pasangan hidupnya dalam gereja, menemukan pemimpin favorit yang dikagumi, menemukan khotbah yang menyenangkan dan suasana ibadah yang menarik disertai musik sesuai konteks mereka, tetapi bisa saja tidak atau belum mengalami perjumpaan pribadi dengan Kristus.

\section{Membina Kaum Muda Menjadi Murid Kristus yang Sejati}

Pelayanan kepada kaum muda tidak berhenti pada perjumpaan dengan Kristus dan menghasilkan orang-orang yang beriman, tetapi juga sampai kepada menjadikan mereka murid Kristus. Begitu banyak orang percaya dalam gereja, tetapi tidak mengerti statusnya sebagai murid Kristus. Orang percaya harus menjadi murid Kristus. Gereja yang hanya menghasilkan orangorang percaya pada akhirnya menghasilkan gereja yang mandul. Sehingga Eva Yunita dengan kritikan yang tajam mengatakan bahwa:

Banyak orang muda kehilangan kreativitasnya begitu masuk gereja. Mereka menjadi orang muda yang pasif, hanya bisa duduk diam menyembah Tuhan, tetapi setelah itu mereka terus jatuh bangun dalam dosa. Mereka sibuk sekali dengan rutinitas kerohanian, tetapi tindakan dan buah kehidupan mereka tidak berubah secara signifikan. Bahkan mereka menjadi orang yang terbelakang dalam banyak hal. Sibuk dengan urusan rohani, tetapi anehnya tidak mengeluarkan buah yang sesuai dengan kesibukan mereka. ${ }^{22}$

Inilah tahap pembinaan yang paling menyenangkan sekaligus penuh tantangan.

Menyenangkan karena merindukan anak-anak muda menjadi murid Kristus, menjadi pribadipribadi yang beriman dan dewasa. Tetapi penuh tantangan sebab dalam pemuridan ini tidak hanya menuntut adanya program gereja yang baik tetapi yang terutama ialah suatu keterlibatan, komitmen, waktu, kesabaran menjalankan proses, dan harapan.

Membuat program tidak sama dengan memuridkan, tetapi pemuridan membutuhkan suatu program. Seperti yang disampaikan oleh Greg Ogden bahwa dalam gereja saat ini, pertumbuhan

\footnotetext{
${ }^{22}$ Eva Yunita, Pemimpin Muda Peka Zaman (Yogyakarta: ANDI, 2009), 2-3.
} 
yang berpusat kepada individu telah diganti dengan berbagai program. Ogden melanjutkan bahwa semua program ini dapat membantu perkembangan pemuridan, namun mereka kehilangan bahan utamanya. Setiap murid merupakan individu yang unik yang bertumbuh pada tingkatan yang berbeda, kecuali jika mereka diperhatikan secara pribadi sehingga kebutuhan mereka untuk bertumbuh dipenuhi dan mereka dipanggil untuk mati bagi diri sendiri dan hidup sepenuhnya bagi Kristus. ${ }^{23}$ Artinya pembinaan kaum muda secara individu adalah program utama dalam memuridkan menjadi murid Kristus. Pemuridan tidak berfokus pada program tetapi kepada setiap individu anak muda.

\section{Menemukan dan Mengembangkan Potensi Kaum Muda}

Pemuda merupakan generasi yang dipundaknya terbebani berbagai macam-macam harapan, terutama dari generasi sebelumnya. Hal ini dapat dimengerti karena pemuda memiliki potensi yang besar sehingga diharapkan pemuda sebagai generasi penerus, generasi yang akan melanjutkan perjuangan generasi sebelumnya, generasi yang mengisi dan melanjutkan estafet pelayanan gereja. Potensi ${ }^{24}$ yang dimiliki kaum muda perlu digali dan dikembangkan. Sebab di luar Kristus potensi ini telah diselewengkan dan digunakan untuk kepentingan diri sendiri. Segala kemampuan yang Tuhan berikan baik bakat atau talenta tidak digunakan untuk kemuliaan Tuhan. Tetapi sebagai kaum muda yang percaya kepada Kristus memiliki potensi bukan hanya bakat dan talenta tetapi juga karunia-karunia rohani yang dari Roh Kudus (1Kor. 12:1-31; Rm. 12:3-8).

Abdipatra ketika membahas hal ini dalam bukunya "Generasi Pembaru", ia menuliskan bahwa tanggung jawab sebagai pemimpin gereja adalah: pertama, membantu setiap orang percaya untuk menemukan dan mengembangkan potensi yang Tuhan berikan sehingga mereka bisa berfungsi dan melayani (1Kor. 12:8, 12, 14, 27). Kedua, memperlengkapi setiap orang percaya sehingga mereka berfungsi dan melakukan pekerjaan pelayanan (Ef. 4:12-16; bnd. 2Tim. 3:16$17) .^{25}$

Dengan demikian, melalui pelayanan gereja akan menghasilkan kaum muda yang beriman dan cerdas sehingga mampu memaksimalkan potensi yang dimiliki untuk menjadi saksi Kristus dalam segala aspek hidupnya.

\section{SIMPULAN}

Kaum muda sebagai generasi yang melanjutkan visi dan misi Tuhan di tengah dunia ini membutuhkan perhatian yang serius dari berbagai pihak, khususnya orang tua dan gereja. Harapan yang besar kepada kaum muda sebagai generasi penerus harus diimbangi dengan perhatian dan

\footnotetext{
${ }^{23}$ Greg Ogden, Transforming Discipleship (Surabaya: Literatur Perkantas Jatim, 2014), 45.

${ }^{24}$ Menurut Philips Tangdilintin, potensi kaum muda memiliki ciri-ciri: Dinamis, berorientasi masa depan, terbuka terhadap setiap perkembangan dan perubahan, kreatif dalam membuat terobosan-terobosan baru, empatik dan memiliki kepekaan sosial yang tinggi. Philips Tangdilintin, Pembinaan Generasi Muda, 27-28.

${ }^{25}$ Budi Abdipatra, Generasi Pembaru, 31-32.
} 
pembinaan yang benar. Bukan hanya perhatian kepada tujuan yang hendak dicapai, tetapi terutama perhatian terhadap masalah yang sedang dihadapi sebagai anak muda. Kaum muda perlu pembinaan untuk menang atas problematik yang begitu kompleks baik internal maupun eksternal. Harapan sebagai generasi penerus yang baik akan tetap jadi harapan apabila kaum muda tidak diperhatikan dan dibina di dalam kebenaran firman Tuhan.

Semoga melalui tulisan singkat ini, orang tua dan para pemimpin gereja semakin mengerti dan memahami masalah sesungguhnya yang sedang dihadapi oleh kaum muda masa kini sehingga termotivasi untuk memberi perhatian dan pembinaan sesuai firman Tuhan. Demikian juga para anak muda akan mengerti dan memahami kondisinya sehingga mau berubah dan dipakai Tuhan untuk kemuliaan-Nya. Soli Deo Gloria.

\section{Daftar Pustaka}

Abdiputra, Budi. Generasi Pembaru. Yogyakarta: Andi Offset, 2009.

Boyd, James W. “O, Give Me A Home” Number 37: Today's Youth Facing Today's Problems. http://www.dawn.com/news/965881/problems-faced-by-the-youth-today (Diakses 20 Juni 2016).

Cury, Augusto. Briliant Parents Fascinating Teachers - Kiat membentuk Generasi Muda yang Cerdas dan Bahagia. Jakarta: Gramedia Pustaka Utama, 2007.

Drew Kuehl, 10 Tantangan Terbesar yang Dihadapi Kaum Muda Saat Ini, http://www.searchthescriptures.org/blog/ what-are-the-ten-biggest-challenges-christian-youthare-facing-today (diakses 18 Juni 2016).

GP, Harianto. Mission for City. Bandung: Agimedia, 2006.

Gunarsa, Y. Singgih D. \& Gunarsa, Singgih, Psikologi Untuk Muda-Mudi. Jakarta: BPK Gunung Mulia, 2004

Jamieson, Robert, dkk., A Commentary Critical, Experimental, and Practical On The Old and New Testament - Volume two part one. Grand Rapids, Michigan: William B. Eerdmans Publishing Company, 1984.

Mangunhardjana, A. M. Pendampingan Kaum Muda. Yogyakarta: Kanisius, 1986.

Mukese, John Dami. Menjadi Manusia Kaya Makna. Jakarta: Obor, 2006.

Ogden, Greg. Transforming Discipleship. Surabaya: Literatur Perkantas Jatim, 2014.

Pfeiffer, Charles F. \& Harrison, Everett F. (ed.), The Wyclif Bible Commentary ed. Bahasa Indonesia. Malang: Gandum Mas, 2004.

Smith, Donald K. Creating Understanding. Ed. Bahasa Indonesia. Yogyakarta: ANDI, 2014. Tacoy, Selvester M. 6 Kunci Sukses Pelayanan Kaum Muda. Bandung: Kalam Hidup, 2009. Tangdilintin, Philips. Pembinaan Generasi Muda. Yogyakarta: Kanisius, 2008.

Yunita, Eva Pemimpin Muda Peka Zaman. Yogyakarta: ANDI, 2009. 